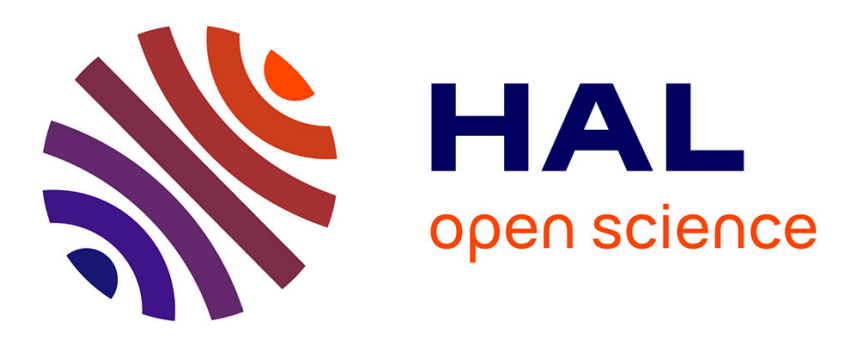

\title{
Adsorption of nitric oxide and temperature programmed desorption on nonstoichiometric nickel-copper manganites
}

Christophe Drouet, Pierre Alphonse, José Luis García Fierro, Abel Rousset

\section{- To cite this version:}

Christophe Drouet, Pierre Alphonse, José Luis García Fierro, Abel Rousset. Adsorption of nitric oxide and temperature programmed desorption on nonstoichiometric nickel-copper manganites. Applied Surface Science, 2001, vol. 174, pp. 289-295. 10.1016/S0169-4332(01)00180-5 . hal-01002019

\section{HAL Id: hal-01002019 https://hal.science/hal-01002019}

Submitted on 6 Jun 2014

HAL is a multi-disciplinary open access archive for the deposit and dissemination of scientific research documents, whether they are published or not. The documents may come from teaching and research institutions in France or abroad, or from public or private research centers.
L'archive ouverte pluridisciplinaire HAL, est destinée au dépôt et à la diffusion de documents scientifiques de niveau recherche, publiés ou non, émanant des établissements d'enseignement et de recherche français ou étrangers, des laboratoires publics ou privés. 


\section{Open Archive TOULOUSE Archive Ouverte (OATAO)}

OATAO is an open access repository that collects the work of Toulouse researchers and makes it freely available over the web where possible.

This is an author-deposited version published in : http://oatao.univ-toulouse.fr/ Eprints ID : 11643

To link to this article : DOI:10.1016/S0169-4332(01)00180-5

URL : http://dx.doi.org/10.1016/S0169-4332(01)00180-5

\section{To cite this version :}

Drouet, Christophe and Alphonse, Pierre and Fierro, José Luis García and Rousset, Abel Adsorption of nitric oxide and temperature programmed desorption on nonstoichiometric nickelcopper manganites. (2001) Applied Surface Science, vol. $174\left(\mathrm{n}^{\circ} 3-\right.$ 4). pp. 289-295. ISSN 0169-4332

Any correspondance concerning this service should be sent to the repository administrator: staff-oatao@ listes-diff.inp-toulouse.fr 


\title{
Adsorption of nitric oxide and temperature programmed desorption on nonstoichiometric nickel-copper manganites
}

\author{
C. Drouet ${ }^{\mathrm{a}}$, P. Alphonse ${ }^{\mathrm{a}, *}$, J.L.G. Fierro ${ }^{\mathrm{b}}$, A. Rousset ${ }^{\mathrm{a}}$ \\ ${ }^{a}$ CIRIMAT-LCMIE, UMR-CNRS 5085, Université Paul Sabatier, Bat. 2R1, 118 route de Narbonne, 31062 Toulouse Cedex 04, France \\ ${ }^{\mathrm{b}}$ Instituto de Catalisis y Petroleoquimica, CSIC, Cantoblanco, 28049 Madrid, Spain
}

\begin{abstract}
The interaction of nitric oxide with nonstoichiometric nickel-copper manganites has been investigated by adsorption and temperature programmed desorption (TPD) experiments. Nitric oxide was found to adsorb molecularly at room temperature on such oxides. Reversibly and irreversibly adsorbed NO molecules were evidenced. The amount of reversibly and irreversibly adsorbed NO increased with the nickel content but decreased with the copper one. Moreover, the ratio reversible/irreversible increased with the copper content of the oxides. TPD experiments indicated that adsorbed NO desorbs at low temperature (below $200^{\circ} \mathrm{C}$ ) mainly as NO molecules (70-90\%). The balance consists of $\mathrm{N}_{2} \mathrm{O}$, a part of which desorbs below $200^{\circ} \mathrm{C}$ and the rest above $250^{\circ} \mathrm{C}$. The area of the peak corresponding to the desorption of nitrous oxide at high temperature is far much larger for copper-free oxides.
\end{abstract}

Keywords: Spinel; Nickel-copper manganites; NO; Adsorption; Temperature programmed desorption

\section{Introduction}

Nonstoichiometric nickel-copper spinel manganites $\mathrm{Ni}_{x} \mathrm{Cu}_{y} \mathrm{Mn}_{(3-x-y)} \square_{3 \delta / 4} \mathrm{O}_{4+\delta}$ are very active catalysts for the reduction of nitric oxide at low temperature with carbon monoxide as reducing agent [1]. These compounds are highly divided materials (specific area above $100 \mathrm{~m}^{2} / \mathrm{g}$ ) and cation-deficient. This nonstoichiometry can be explained by the presence of cations with larger oxidation states than in stoichiometric oxides, inducing the presence of cationic vacancies. For instance, $\mathrm{Ni}^{3+}, \mathrm{Mn}^{3+}$ and $\mathrm{Mn}^{4+}$ cations can be formed by oxidation of $\mathrm{Ni}^{2+}, \mathrm{Mn}^{2+}$ and
$\mathrm{Mn}^{3+}$ cations, respectively, during the oxides synthesis in air at low temperature. Upon heating in Ar, these nonstoichiometric oxides have been shown to loose part of their lattice oxygen in several steps tending to the stoichiometric formulae. Moreover, the amount of oxygen released in the gas phase as measured by gas chromatography enabled to determine the level of nonstoichiometry $\delta$ ( $\delta$ generally lied between 0.20 and 0.80 ).

Recent chemisorption experiments [2] carried out under static conditions have shown the competitive adsorption behaviour of $\mathrm{NO}$ and $\mathrm{CO}$ molecules on such compounds, and a close relationship between the chemical composition of the oxides and the equilibrium coverages was also observed. With the aim to better understand the high reactivity of these new spinel materials, NO adsorption (under flowing conditions) and temperature programmed desorption 
(TPD) of nitric oxide have been undertaken and the results obtained are reported in this paper.

\section{Experimental}

\subsection{Oxide preparation}

The nonstoichiometric nickel-copper manganites $\mathrm{Ni}_{x} \mathrm{Cu}_{y} \mathrm{Mn}_{(3-x-y)} \square_{3 \delta / 4} \mathrm{O}_{4+\delta}$ were synthesised by thermal decomposition in air at $350^{\circ} \mathrm{C}$ for $6 \mathrm{~h}$ of mixed nickel-copper-manganese oxalates precipitated at room temperature in aqueous conditions (see [3] for additional details). The nominal composition, level of nonstoichiometry and specific surface area of the samples studied here are reported in Table 1.

\subsection{Adsorption of nitric oxide}

The sample was placed in a U-type microreactor (quartz) located in a tubular oven. After a pretreatment in $\mathrm{O}_{2}(20 \%) / \mathrm{Ar}(80 \%)$ at $300^{\circ} \mathrm{C}$ for $1 \mathrm{~h}$, the temperature was set to $20^{\circ} \mathrm{C}$, then the flow was replaced by pure argon. The adsorption of nitric oxide was performed at room temperature under $900 \mathrm{ppm} \mathrm{NO} / \mathrm{Ar}$, maintaining a constant flow of $60 \mathrm{~cm}^{3} / \mathrm{min}$. After $40 \mathrm{~min}$, the atmosphere was again set to pure argon. During the adsorption step, helium was added to the gas mixture as a tracer.

\subsection{Temperature programmed desorption of nitric oxide}

The TPD of nitric oxide was carried out by increasing linearly the temperature of the NO-preadsorbed sample at $\beta=5^{\circ} \mathrm{C} / \mathrm{min}$. During the adsorption and desorption steps, the inlet or outlet gas composition

Table 1

Composition, surface area and level of nonstoichiometry $\delta$ of the investigated oxides

\begin{tabular}{lll}
\hline Chemical composition & $S\left(\mathrm{~m}^{2} / \mathrm{g}\right)$ & $\delta$ \\
\hline $\mathrm{Ni}_{0.25} \mathrm{Mn}_{2.75} \square_{3 \delta / 4} \mathrm{O}_{4+\delta}$ & 165 & $0.48 \pm 0.03$ \\
$\mathrm{Ni}_{0.70} \mathrm{Mn}_{2.30} \square_{3 \delta / 4} \mathrm{O}_{4+\delta}$ & 180 & $0.65 \pm 0.05$ \\
$\mathrm{Ni}_{0.25} \mathrm{Cu}_{0.80} \mathrm{Mn}_{1.95} \square_{3 \delta / 4} \mathrm{O}_{4+\delta}$ & 150 & $0.40 \pm 0.03$ \\
$\mathrm{Ni}_{0.70} \mathrm{Cu}_{0.65} \mathrm{Mn}_{1.65} \square_{3 \delta / 4} \mathrm{O}_{4+\delta}$ & 160 & $0.27 \pm 0.02$ \\
$\mathrm{Ni}_{0.70} \mathrm{Cu}_{0.91} \mathrm{Mn}_{1.39} \square_{3 \delta / 4} \mathrm{O}_{4+\delta}$ & 140 & $0.22 \pm 0.02$ \\
\hline
\end{tabular}

was determined by a BALZERS QMG 421G quadrupole mass spectrometer.

\section{Results}

\subsection{Adsorption of nitric oxide}

During the adsorption of nitric oxide at room temperature, the evolution of the outlet gas composition was determined. In particular, the ratios $m / e=30$ and 4 , corresponding respectively to $\mathrm{NO}$ and $\mathrm{He}$, were followed during the cycle "argon $\rightarrow 900 \mathrm{ppm}$ $\mathrm{NO} / \mathrm{Ar} \rightarrow$ argon" in the case of the oxide $\mathrm{Ni}_{0.70} \mathrm{Cu}_{0.65} \mathrm{Mn}_{1.65} \square_{3 \delta / 4} \mathrm{O}_{4+\delta}$ (Fig. 1). The area between the $\mathrm{NO}(m / e=30)$ and $\mathrm{He}(m / e=4)$ responses was interpreted as an initial $\mathrm{NO}$ adsorption (denoted " $a$ ") when the sample was exposed to NO, followed by NO desorption (denoted " $a_{\mathrm{r}}$ ") when the NO flow was replaced by an Ar flow.

For the adsorption step, about $1500 \mathrm{~s}$ were needed to obtain a stabilisation of the outlet gas composition (superimposition of the two curves). After return in pure argon, about $2000 \mathrm{~s}$ were necessary to reach equilibrium evidencing a room temperature-desorption step.

\subsection{Temperature programmed desorption of nitric oxide}

After the room temperature-desorption step, and maintaining the sample under a flow of argon, the temperature was linearly increased and the outlet gas composition was monitored by mass spectrometry. During these TPD experiments, only a variation of the ratios $m / e=30$ (due to $\mathrm{NO}$ ), $m / e=44$ and 32 (this last value corresponding to the release of nonstoichiometric oxygen) was observed. Note that no variation of the ratio $m / e=12$ (related to carbon) was observed during the heating of the sample, which indicates the absence of $\mathrm{CO}_{2}$ and makes the ratio $m / e=44$ undoubtedly attributable to nitrous oxide $\mathrm{N}_{2} \mathrm{O}$. No other nitrogen-containing species (like $\mathrm{NO}_{2}$ or $\mathrm{N}_{2}$ ) was detected.

\subsubsection{Desorption as NO molecules}

The concentration of nitric oxide in the gas phase was monitored during the thermo-desorption in the 


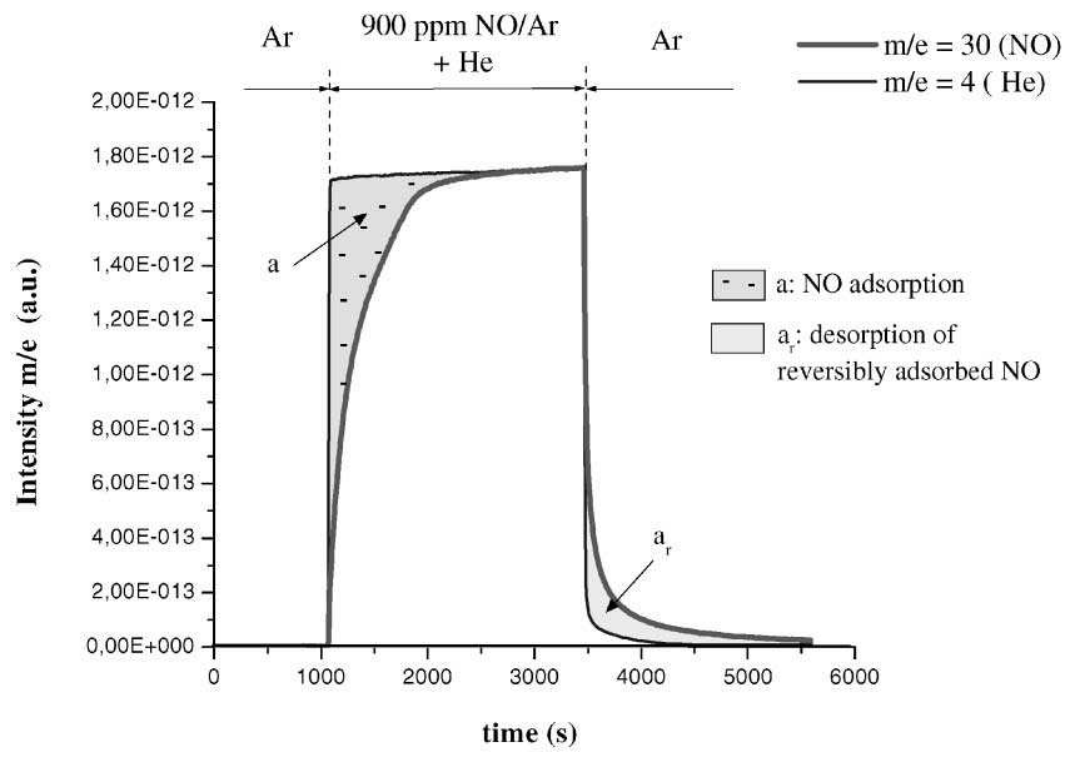

Fig. 1. Adsorption of $\mathrm{NO}\left(900 \mathrm{ppm} \mathrm{NO} / \mathrm{Ar}, 60 \mathrm{~cm}^{3} / \mathrm{min}\right.$ ), at $25^{\circ} \mathrm{C}$, on the oxide $\mathrm{Ni}_{0.70} \mathrm{Cu}_{0.65} \mathrm{Mn}_{1.65} \square_{3 \delta / 4} \mathrm{O}_{4+\delta}$.

case of several nickel and nickel-copper manganites (Fig. 2). Several desorption steps were observed. In all cases, two desorption peaks (noted peaks (1) and (2)), whose intensity depend on the chemical composition of the oxide, could be easily identified at ca. 55 and $80^{\circ} \mathrm{C}$. Above $100^{\circ} \mathrm{C}$, a succession of poorly-defined desorption steps was also noticeable. Many works have been devoted to the resolution of thermo-

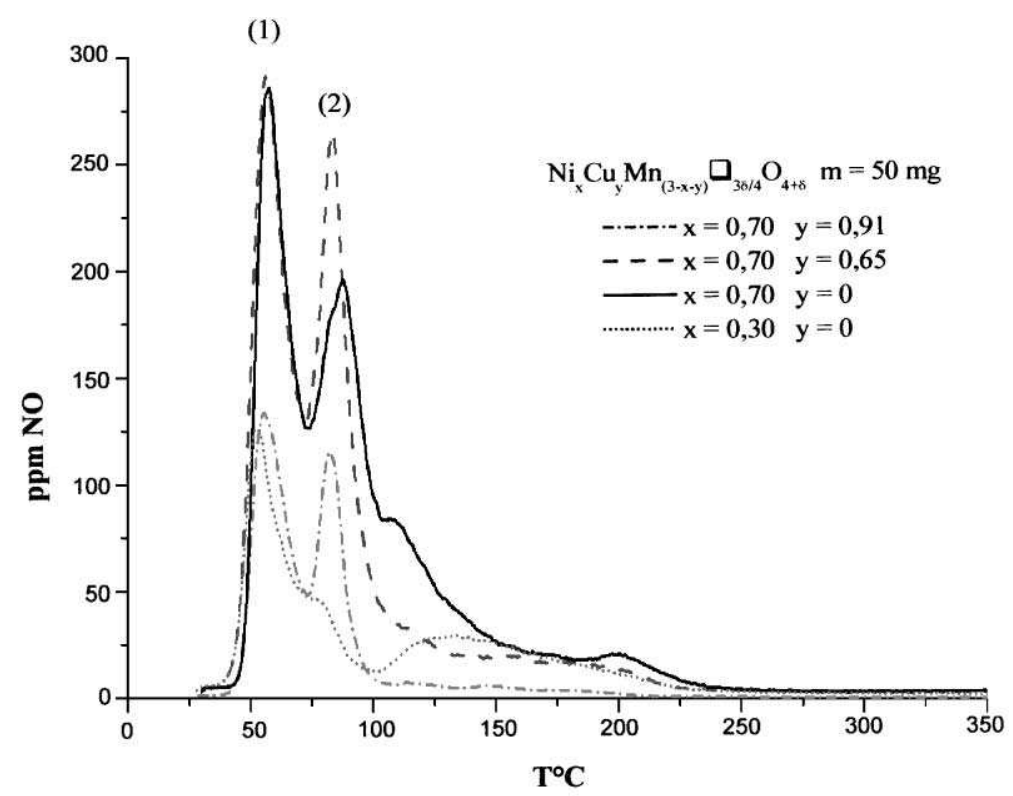

Fig. 2. Thermo-desorption of nitric oxide as NO molecules as a function of the temperature. 


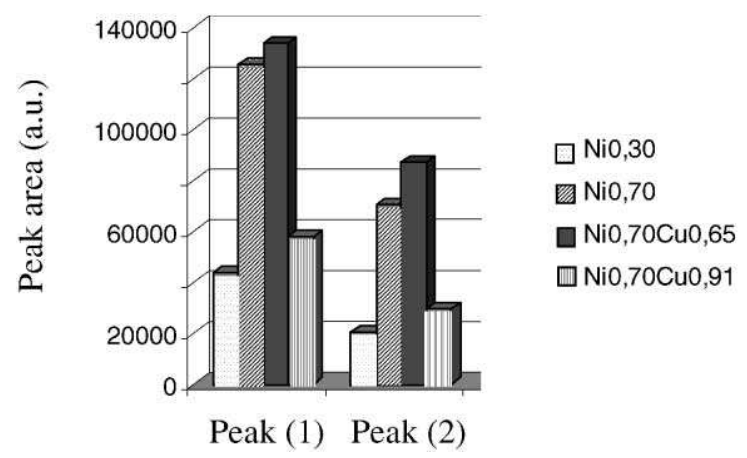

Fig. 3. Evolution of the area of NO desorption peaks (1) and (2) for several manganites.

desorption spectra and the analysis of the shape of the desorption peaks $[4,5]$. In our case, the best fitting between the experimental curve (presenting asymmetrical peaks) and a theoretical model was obtained using the exponential function $y=A \exp [-\exp (-z)-$ $z+1]$ to represent each peak (with $z=\left(x-x_{\max }\right) / w$, where " $x_{\max }$ " stands for the position of the maximum of the peak and " $w$ " is the full width at half maximum (FWHM) of the peak). The area of the desorption peaks (1) and (2), determined thanks to this procedure, was found to (see Fig. 3) increase with the nickel content $x_{\mathrm{Ni}}$ of the oxide, but to decrease slightly above a maximum value of the copper content $\left(y_{\mathrm{Cu}}>0.65\right)$.

\subsubsection{Desorption as $\mathrm{N}_{2} \mathrm{O}$ molecules}

The desorption peaks of $\mathrm{N}_{2} \mathrm{O}(m / e=44)$ detected for the different manganites (Fig. 4) could be classified in two temperature regions: $\mathrm{N}_{2} \mathrm{O}$ desorbed at "low temperature" $\left(50-200^{\circ} \mathrm{C}\right)$ and $\mathrm{N}_{2} \mathrm{O}$ desorbed at "high temperature" $\left(275-400^{\circ} \mathrm{C}\right)$. Here again, the total quantity of desorbed $\mathrm{N}_{2} \mathrm{O}$ increases with $x_{\mathrm{Ni}}$ but decreases for high copper contents. Finally, it is interesting to note that, in the case of the oxide $\mathrm{Ni}_{0.70} \mathrm{Cu}_{0.91} \mathrm{Mn}_{1.39} \square_{3 \delta / 4} \mathrm{O}_{4+\delta}$, an additional desorption peak of $\mathrm{N}_{2} \mathrm{O}$ was observed at ca. $305^{\circ} \mathrm{C}$ (see arrow in Fig. 4).

\subsubsection{Thermo-desorption of $\mathrm{NO}$ for $\mathrm{a}^{18} \mathrm{O}_{2}$ - pretreated oxide}

In order to determine the type of adsorption (molecular or dissociative) of nitric oxide on such oxide surfaces, $\mathrm{NO}$ was adsorbed at room temperature on a sample $\left(\mathrm{Ni}_{0.70} \mathrm{Cu}_{0.65} \mathrm{Mn}_{1.65} \square_{3 \delta / 4} \mathrm{O}_{4+\delta}\right)$ pretreated with $5 \%{ }^{18} \mathrm{O}_{2} / \mathrm{Ar}$ at $150{ }^{\circ} \mathrm{C}$ for $20 \mathrm{~min}$. During the thermo-desorption, the mass profiles $m / e=32$ (corresponding to the species $\mathrm{N}^{18} \mathrm{O}$ or ${ }^{16} \mathrm{O}_{2}$ ) and $m / e=34$ (related to ${ }^{16} \mathrm{O}^{18} \mathrm{O}$ ) were recorded (Fig. 5). For comparative purposes, the variation of the ratio $m / e=30$ corresponding to NO has also been reported. The intensity of the ratios $m / e=32$ and 34 increase from ca. $225^{\circ} \mathrm{C}$. On the contrary, no increase of $m / e=34$ was observed in the temperature range $20-200^{\circ} \mathrm{C}$.

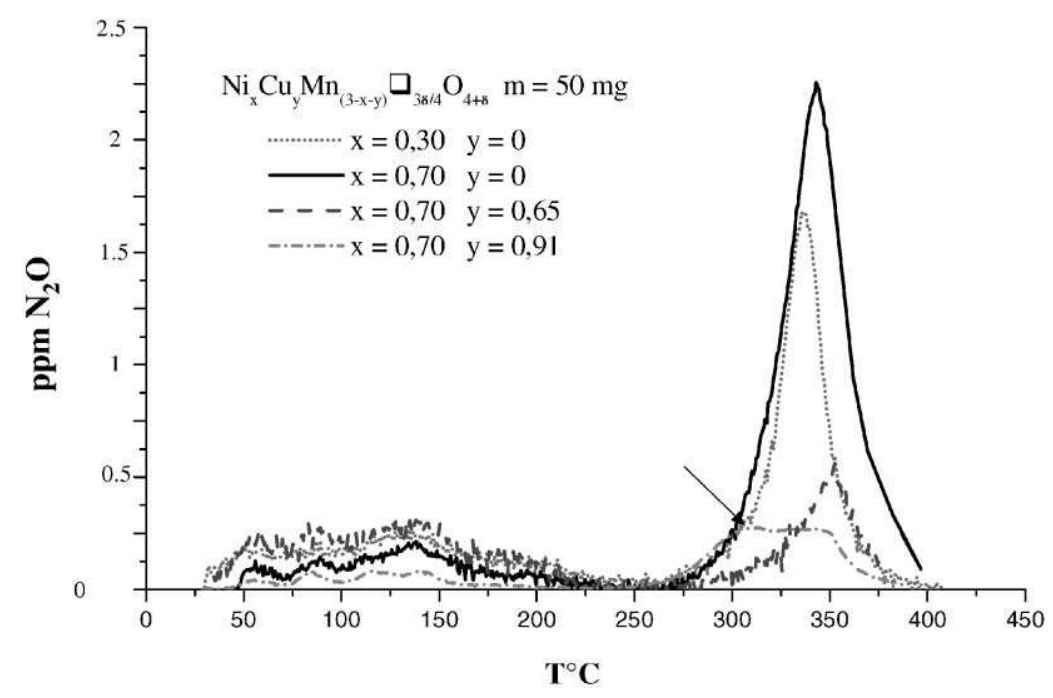

Fig. 4. Thermo-desorption of nitric oxide as $\mathrm{N}_{2} \mathrm{O}$ molecules as a function of the temperature. 


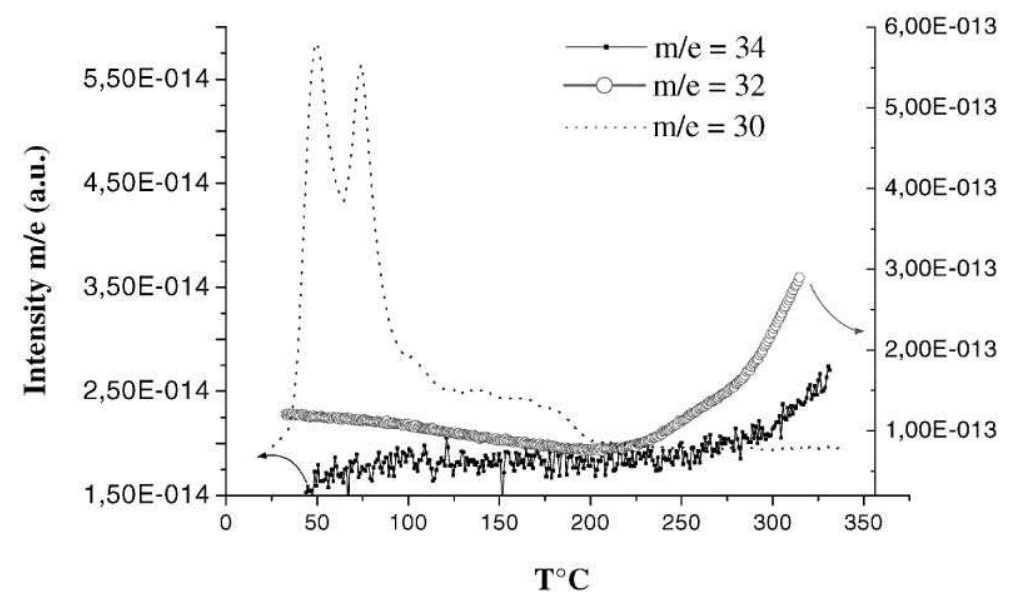

Fig. 5. Evolution of the ratios $m / e=30,32$ and 34 during the NO thermo-desorption in $\operatorname{argon}\left(\beta=5^{\circ} \mathrm{C} / \mathrm{min}\right)$ for the oxide $\mathrm{Ni}_{0.70} \mathrm{Cu}_{0.65} \mathrm{Mn}_{1.65} \square 3 \delta / 4 \mathrm{O}_{4+\delta}$ pretreated with ${ }^{18} \mathrm{O}_{2}$.

\section{Discussion}

Helium does not interact with the oxide surface. Thus, the helium response indicates the position that the NO curve should have presented without interactions with the sample surface. During the adsorption step, the NO response was below that of helium (delimiting the area " $a$ ") because the concentration of nitric oxide in the gas phase was lower than the value expected in the absence of interactions, which can obviously be explained by the adsorption of NO on the surface of the sample. The equilibrium was attained from ca. $2000 \mathrm{~s}$ of contact between $\mathrm{NO}$ and the sample. After the flow switching "NO/Ar $\rightarrow$ argon", the NO response was now above that of helium, which delimited the area " $a_{\mathrm{r}}$ " between the two curves. This observation indicates that part of the adsorbed NO molecules desorbed when the sample returned to an inert atmosphere. Thus, two types of adsorbed NO can be discerned: reversibly and irreversibly adsorbed. The amounts of NO reversibly and irreversibly adsorbed can be directly related to the areas " $a_{\mathrm{r}}$ " and " $a-a_{\mathrm{r}}$ ", respectively, and compared for several manganites (Table 2). The comparison between the copper-free oxides $\left(\mathrm{Ni}_{0.25} \mathrm{Mn}_{2.75} \square_{3 \delta / 4} \mathrm{O}_{4+\delta}\right.$ and $\mathrm{Ni}_{0.70} \mathrm{Mn}_{2.30} \square_{3 \delta / 4} \mathrm{O}_{4+\delta}$ ) points out that the amounts of reversibly and irreversibly adsorbed NO largely increase with the nickel content of the oxides. This conclusion is in accordance with the results obtained previously from chemisorption experiments on such oxides [2] showing the high increase of NO coverage in the case of nickel manganites compared to manganese oxide $\mathrm{Mn}_{3} \mathrm{O}_{4}$. The comparison of nickel-copper manganites containing a

Table 2

Amounts of totally, reversibly and irreversibly adsorbed NO on the studied oxides

\begin{tabular}{|c|c|c|c|c|c|c|c|}
\hline \multicolumn{2}{|c|}{ Oxide composition } & \multicolumn{6}{|c|}{ Adsorbed NO } \\
\hline \multirow[t]{2}{*}{$x_{\mathrm{Ni}}$} & \multirow[t]{2}{*}{$y_{\mathrm{Cu}}$} & \multicolumn{2}{|l|}{ Totally } & \multicolumn{2}{|l|}{ Irreversibly } & \multicolumn{2}{|l|}{ Reversibly } \\
\hline & & $10^{-4} \mathrm{~mol} / \mathrm{g}$ & $10^{-6} \mathrm{~mol} / \mathrm{m}^{2}$ & $10^{-4} \mathrm{~mol} / \mathrm{g}$ & $10^{-6} \mathrm{~mol} / \mathrm{m}^{2}$ & $10^{-4} \mathrm{~mol} / \mathrm{g}$ & $10^{-6} \mathrm{~mol} / \mathrm{m}^{2}$ \\
\hline 0.25 & 0 & 1.4 & 0.85 & 1.0 & 0.61 & 0.4 & 0.24 \\
\hline 0.25 & 0.80 & 1.0 & 0.67 & 0.4 & 0.29 & 0.6 & 0.38 \\
\hline 0.70 & 0 & 2.4 & 1.33 & 1.5 & 0.86 & 0.9 & 0.48 \\
\hline 0.70 & 0.65 & 1.9 & 1.19 & 1.2 & 0.73 & 0.7 & 0.46 \\
\hline 0.70 & 0.91 & 1.1 & 0.79 & 0.5 & 0.38 & 0.6 & 0.41 \\
\hline
\end{tabular}


fixed nickel content but variable copper contents shows that the amounts of reversibly and irreversibly adsorbed NO tend to decrease with increasing copper content, while the ratio reversible/irreversible increases.

The results reported before may be related to the stability of the surface species formed between NO and nickel, copper and manganese cations. Then, the following stability order could be assumed in the case of the adsorption of $\mathrm{NO}$ on nonstoichiometric nickelcopper manganites:

$\mathrm{Ni}^{n+}-\mathrm{NO}>\mathrm{Mn}^{n+}-\mathrm{NO}>\mathrm{Cu}^{n+}-\mathrm{NO}$

During the thermo-desorption experiments, only the variation of the ratios $m / e=30$ and 44 has been detected, corresponding to the desorption of NO and $\mathrm{N}_{2} \mathrm{O}$. The absence of nitrogen or oxygen (except for nonstoichiometric oxygen) allows to conclude that the adsorption of $\mathrm{NO}$ at $20^{\circ} \mathrm{C}$ on such oxides is a nondissociative process.

The presence of an intense desorption peak of $\mathrm{NO}$ at a temperature as low as $55^{\circ} \mathrm{C}$ (Fig. 2) evidences the presence of weakly bound surface species, and similar conclusions have already been drawn in the case of copper-alumina compounds [6]. The occurrence of different desorption peaks can be due to several causes [7-9]: (i) presence of distinct adsorption sites; (ii) formation of various surface species; and/or (iii) existence of interactions between the adsorbed molecules leading to a variation of the activation energy for the desorption of $\mathrm{NO}$ as a function of the coverage. The deconvolution of the experimental desorption curves showed (see Fig. 3) that the intensity of both peaks (1) and (2) increased with increasing nickel content, but decreased for high copper contents. This was expected in view of the adsorption results and might also be explained by a difference in stability of the surface species formed between NO and nickel, copper or manganese cations.

The desorption of $\mathrm{N}_{2} \mathrm{O}$ molecules also occurs with successive steps (Fig. 4). The desorption profiles can be divided into two principal parts: $\mathrm{N}_{2} \mathrm{O}$ desorbing at low temperature $\left(50-200^{\circ} \mathrm{C}\right.$ ) and $\mathrm{N}_{2} \mathrm{O}$ desorbing at higher temperature $\left(275-400^{\circ} \mathrm{C}\right)$. It can be assumed that these two desorption processes of nitrous oxide have distinct origins. The combination of $\mathrm{NO}$ adsorbed molecules to form adsorbed nitrous oxide and oxygen adatoms has already been reported in some cases [10], and this interpretation could account here for the desorption of $\mathrm{N}_{2} \mathrm{O}$ at low temperature. On the other hand, the nitrous oxide desorbing at high temperatures might come from the thermal decomposition of rather strongly bound surface species such as nitrites or nitrates as reported by Davydov [11] in the case of $\mathrm{Fe}_{2} \mathrm{O}_{3}$. Furthermore, it is interesting to note that the intensity of the peak corresponding to the desorption of $\mathrm{N}_{2} \mathrm{O}$ at high temperature is far much larger in the case of copper-free oxides, which could be explained by a lower implication of copper in the formation of nitrites/nitrates surface species on such oxides.

The occurrence of an additional $\mathrm{N}_{2} \mathrm{O}$ desorption peak at ca. $305^{\circ} \mathrm{C}$ in the case of manganites containing high copper contents could be related to the existence of traces of a second phase containing copper, highly dispersed, as already confirmed by XPS analyses [12].

The comparison between the amounts of adsorbed and desorbed nitric oxide (Table 3) shows that adsorbed nitric oxide mainly desorbs as NO molecules in all cases, and this trend is accentuated when the nickel and copper contents of the oxides increase.

When NO adsorption was carried out on an oxide pretreated with $5 \%{ }^{18} \mathrm{O}_{2} / \mathrm{Ar}$, no exchanged species like $\mathrm{N}^{18} \mathrm{O}(m / e=32)$ or ${ }^{16} \mathrm{O}^{18} \mathrm{O}(m / e=34)$ was observed below $200^{\circ} \mathrm{C}$, i.e. during $\mathrm{NO}$ desorption (Fig. 5). From $225^{\circ} \mathrm{C}$, the increase of the ratios $m / e=32\left({ }^{16} \mathrm{O}^{16} \mathrm{O}\right)$ and $m / e=34\left({ }^{16} \mathrm{O}^{18} \mathrm{O}\right)$ are due to the release of the nonstoichiometric oxygen of the oxides [3]. The presence of ${ }^{16} \mathrm{O}^{18} \mathrm{O}$ indicates that part of the surface oxygen ${ }^{16} \mathrm{O}$ of the oxide has effectively been exchanged with ${ }^{18} \mathrm{O}$ during the pretreatment in ${ }^{18} \mathrm{O}_{2}$. Hence, the absence of $\mathrm{N}^{18} \mathrm{O}$ during the NO desorption $\left(20-200^{\circ} \mathrm{C}\right)$ confirms that the adsorption

Table 3

Amounts of adsorbed and desorbed NO on the studied oxides

\begin{tabular}{llll}
\hline $\begin{array}{l}\text { Oxide } \\
\text { composition }\end{array}$ & $\begin{array}{l}\text { Amount of } \\
\text { adsorbed } \\
\text { NO }(\mathrm{mol} / \mathrm{g})\end{array}$ & \multicolumn{2}{l}{$\begin{array}{l}\text { Amount of } \\
\text { desorbed NO (\%) }\end{array}$} \\
\cline { 3 - 4 } & $1.0 \times 10^{-4}$ & 68 & $\mathrm{~N}_{2} \mathrm{O}$ \\
\hline $\mathrm{Ni}_{0.30} \mathrm{Mn}_{2.70} \mathrm{O}_{4+\delta}$ & $1.5 \times 10^{-4}$ & 80 & 32 \\
$\mathrm{Ni}_{0.70} \mathrm{Mn}_{2.30} \mathrm{O}_{4+\delta}$ & $1.2 \times 10^{-4}$ & 88 & 20 \\
$\mathrm{Ni}_{0.70} \mathrm{Cu}_{0.65} \mathrm{Mn}_{1.65} \mathrm{O}_{4+\delta}$ & $0.5 \times 10^{-4}$ & 86 & 12 \\
$\mathrm{Ni}_{0.70} \mathrm{Cu}_{0.91} \mathrm{Mn}_{1.39} \mathrm{O}_{4+\delta}$ & & & 14 \\
\hline
\end{tabular}

${ }^{\mathrm{a}}$ Irreversibly adsorbed NO. 
at $20^{\circ} \mathrm{C}$ of nitric oxide on such nonstoichiometric nickel-copper manganites is not dissociative.

\section{Conclusions}

Adsorption of nitric oxide, at room temperature, on nonstoichiometric nickel-copper manganites $\mathrm{Ni}_{x} \mathrm{Cu}_{y^{-}}$ $\mathrm{Mn}_{(3-x-y)} \square_{3 \delta / 4} \mathrm{O}_{4+\delta}$ shows that two types of adsorbed NO can be discerned: reversible and irreversible. The amounts of reversibly and irreversibly adsorbed NO depend on the chemical composition of the oxide: it increases with $x_{\mathrm{Ni}}$ and decreases with $y_{\mathrm{Cu}}$. Moreover, the ratio reversible/irreversible increases with the concentration of copper in the manganite. These results could be related to the stability of the surface species formed between NO and the cations of the spinel.

TPD experiments have shown that, even if nitric oxide desorbs mainly as $\mathrm{NO}$ molecules, and at rather low temperature $\left(50-200^{\circ} \mathrm{C}\right)$, a $10-30 \%$ of adsorbed $\mathrm{NO}$ desorbs as $\mathrm{N}_{2} \mathrm{O}$. Two desorption processes of $\mathrm{N}_{2} \mathrm{O}$ have been evidenced: at low temperature $\left(50-200^{\circ} \mathrm{C}\right)$, and at higher temperature $\left(275-400^{\circ} \mathrm{C}\right)$. They might come from the thermal decomposition of distinct surface species.

\section{References}

[1] C. Drouet, P. Alphonse, A. Rousset, Appl. Catal. B: Environ., submitted for publication.

[2] C. Drouet, P. Alphonse, J.L.G. Fierro, A. Rousset, J. Colloid Interface Sci. 225 (2000) 440.

[3] C. Drouet, P. Alphonse, A. Rousset, Solid State Ionics 123 (1999) 25

[4] P.A. Redhead, Vacuum 12 (1962) 203

[5] G. Carter, Vacuum 12 (1962) 245.

[6] A. Sepulveda, C. Marquez, I. Rodriguez-Ramos, A. GuerreroRuiz, J.L.G. Fierro, Surf. Interface Anal. 20 (1993) 1067.

[7] P.T. Dawson, P.C. Walker, in: R.B. Anderson, P.T. Dawson (Eds.), Experimental Methods in Catalytic Research, Vol. 3, Academic Press, New York, 1976.

[8] F.C. Tompkins, Chemisorption of Gases on Metals, Academic Press, New York, 1978.

[9] J.M. Thomas, W.J. Thomas, Principles and Practice of Heterogeneous Catalysis, VCH, New York, 1997.

[10] T.J. Udovic, J.A. Dumesic, J. Catal. 89 (1984) 314.

[11] A.A. Davydov, Y.A. Lokhov, Y.M. Shchekochikhin, Kinetics Catal. 19 (1978) 532.

[12] C. Drouet, C. Laberty, J.L.G. Fierro, P. Alphonse, A. Rousset, Intern. J. Inorg. Mater. 2 (2000) 419. 